\title{
Hepatitis B infection in households of acute cases
}

\author{
$\mathrm{K}$ T GOH,${ }^{1} \mathrm{~J}$ L DING,${ }^{2}$ E H MONTEIRO,${ }^{3}$ AND C J OON ${ }^{2}$
}

From the Quarantine \& Epidemiology Department, ${ }^{1}$ Ministry of the Environment, Princess House, Alexandra Road, Singapore 0315; University Department of Medicine (I), ${ }^{2}$ Singapore General Hospital; and Middleton Hospital, ${ }^{3}$ Ministry of Health, Singapore

SUMMARY Seroepidemiological studies conducted in 369 household contacts of 80 acute cases of hepatitis B in Singapore showed that asymptomatic chronic carriers of hepatitis B surface antigen ( $\mathrm{HBs} \mathrm{Ag}$ ) are the main source of acute hepatitis B infection. The $\mathrm{HBs} \mathrm{Ag}$ prevalence rate in asymptomatic household members was $20 \%$ compared with a $6 \%$ prevalence for the general population. The majority of the household carriers $(60 \%)$ were highly infectious with positive hepatitis e antigen ( $\mathrm{HBe} \mathrm{Ag}$ ). The overall prevalence of $\mathrm{HBV}$ infection (with at least one HBV marker) of the household contacts was $40.7 \%$. Spouses and parents of acute cases had a significantly higher prevalence of HBV infection than other members of the families. HBV prevalence rate showed no association with the household size. Factors associated with the risk of transmission of HBV infection included sharing of various personal and household articles, such as toothbrush, towel, handkerchief, clothing, razor, comb, bed and bedding. Sleeping in the same bedroom, eating together at meals, and sharing of eating and drinking utensils were not associated with an increased risk of transmission of infection. Follow-up studies six months later showed that $30 \%$ of the acute cases became chronic $\mathrm{HBs} \mathrm{Ag}$ carriers (with $46 \% \mathrm{HBe} \mathrm{Ag}$ positive), thus providing an additional source of infection in the families, while $8 \%$ of the susceptible household members acquired asymptomatic HBV infection. Health education on the prevention of HBV transmission in the homes of acute cases should be based on sound epidemiological information. Household contacts of acute cases of hepatitis B should be routinely screened and the susceptibles vaccinated against the disease as soon as possible.

Most sporadic cases of acute hepatitis $B$ acquired the infection from hepatitis B surface antigen (HBs Ag) carriers via non-parenteral or inapparent parenteral route. ${ }^{12}$ Intrafamilial transmission of asymptomatic hepatits $B$ virus (HBV) infection is the major epidemiological factor in determining the prevalence of infection in household contacts of $\mathrm{HBs} \mathrm{Ag}$ carriers. $^{3-9}$ Up to $40 \%$ of babies born to carrier mothers in endemic areas may acquire the infection during the perinatal period. ${ }^{10-11}$ Other modes of transmission such as through bites of mosquitoes and other blood sucking insects ${ }^{12}{ }^{13}$ and environmental contamination by tropical ulcers ${ }^{14}$ have been postulated to account for the high hepatitis B endemicity in tropical countries. In Singapore, where the annual morbidity rate of acute viral hepatitis ranged from 24 to 46 per 100000 population, HBV is responsible for $46 \%$ of the cases during the non-epidemic period. ${ }^{15}$ Perinatal transmission occurred in $48 \%$ of the babies born to HBs Ag carrier mothers, $34 \%$ with a stable carrier state. But it could account for only $23 \%$ of the HBs Ag carrier rate in 1-year-old children. ${ }^{16}$ The majority of the infection must have been acquired horizontally from carriers within the same household.

An epidemiological enquiry was therefore conducted to determine the extent of HBV infection and its route and vehicle of spread from person to person in the households of acute hepatitis B cases.

\section{Materials and methods}

The study population consisted of all hospitalised acute cases of hepatitis B with a compatible history, raised liver transaminase levels, and presence of HBs Ag notified to the Quarantine and Epidemiology Department, Ministry of the Environment, between June 1982 and May 1983. The homes were visited and relevant epidemiological data were collected by a well trained public health inspector in a standardised questionnaire from the acute cases and their home contacts. The information obtained included history 
of various parenteral procedures such as injection, vaccination, venepuncture, blood transfusion, surgery, dental treatment, tattooing, intravenous drug abuse, ear piercing and acupuncture, overseas travel and contact with jaundiced persons during the preceding six months. No attempt was made to elicit sexual practices of adult family members. All household members were bled at Middleton Hospital as soon as possible after acute hepatitis B had been diagnosed. They were kept under surveillance for a minimum period of six months.

As it was anticipated that it would be very difficult to obtain a second specimen from all the acute cases and their home contacts, and to minimise non-compliance, half of the study population was chosen with the aid of tables of random sampling numbers and bled for the second time six months later. During the second home visits, household members were interviewed as to whether or not they had frequently shared personal and household items such as towel, handkerchief, razor, toothbrush, eating and drinking utensils, nail clippers, and comb, and slept in the same bed and bedroom with the acute cases during the past year.

Sera were stored at $-20^{\circ} \mathrm{C}$ and subsequently tested for various $\mathrm{HBV}$ markers by enzyme immunoassay at the Ransome Research Laboratory, Singapore General Hospital. The markers assayed were HBs $\mathrm{Ag}$ (by AUSZYME II), $\mathrm{HBe} \mathrm{Ag}$ (ie, hepatitis e antigen by Abbott HBe-EIA), anti-HBc (ie, antibody to hepatitis $B$ core antigen by CORZYME), and anti-HBs (ie, antibody to hepatitis B surface antigen by AUSAB-EIA).

\section{Results}

A total of 80 families with 369 home contacts were included in the study. Seven families were excluded as blood specimens could not be obtained from some of the home contacts.
H B V MARK ERS

Sixty eight $(85 \%)$ of the families studied had at least one other member with evidence of past HBV infection (ie, presence of one or more $\mathrm{HBV}$ markers). Of the home contacts, $150(40.7 \%)$ were asymptomatically infected, $30(20 \%)$ being HBs Ag carriers (table 1). Eighteen $(60 \%)$ of the carriers were highly infectious with positive $\mathrm{HBe} \mathrm{Ag}$. The majority of these carriers (16 out of 18 or $88.9 \%$ ) were found in home contacts under 25 years of age. The ratio of icteric to asymptomatic $\mathrm{HBV}$ infection in the household members was 1:1.9.

Table 1 Serological results of 80 acute cases of hepatitis $B$ and 369 home contacts

\begin{tabular}{lcc}
\hline & $\begin{array}{l}\text { Acute } \\
\text { cases }\end{array}$ & $\begin{array}{l}\text { Asymptomatic } \\
\text { home contacts }\end{array}$ \\
\hline $\mathrm{HBs} \mathrm{Ag}$ alone & 3 & 1 (carrier) \\
$\mathrm{HBs} \mathrm{Ag} / \mathrm{HBe} \mathrm{Ag}$ & 4 & 0 \\
$\mathrm{HBs} \mathrm{Ag/HBe} \mathrm{Ag} /$ anti-HBc & 56 & 18 (carrier) \\
$\mathrm{HBs} \mathrm{Ag/anti-HBc}$ & 17 & 11 (carrier) \\
anti-HBc/anti-HBS & 0 & 95 (past infection) \\
anti-HBs alone & 0 & 7 (past infection) \\
anti-HBc alone & 0 & 18 (past infection/carrier) \\
No markers* & 0 & 219 (susceptible) \\
Any marker (combined) & 80 & 369
\end{tabular}

* Persons with no HBV markers at the time of testing

EPIDEMIOLOG Y

While acute hepatitis $B$ infection involve predominantly males in the 15-34 year age group asymptomatic home contacts of both sexes were equally affected. A high prevalence rate of infection was noted in children under 5 years of age; it dropped in the 5-14 year age group and then gradually increased subsequently so that by 65 years of age all the home contacts were infected (table 2). Among the three major ethnic groups in Singapore, the prevalence of HBV infection of the Chinese and of

Table 2 Age-sex distribution of 80 acute cases of hepatitis B and age-sex-specific infection rate of 369 home contacts

\begin{tabular}{|c|c|c|c|c|c|c|c|c|c|c|c|c|}
\hline \multirow{3}{*}{$\begin{array}{l}\text { Age } \\
\text { group } \\
\text { (yr) }\end{array}$} & \multirow{2}{*}{\multicolumn{3}{|c|}{ Acute cases }} & \multicolumn{9}{|c|}{ Home contacts } \\
\hline & & & & \multicolumn{3}{|l|}{ Male } & \multicolumn{3}{|c|}{ Female } & \multicolumn{3}{|c|}{ Total } \\
\hline & Male & Female & Total & No & $\begin{array}{l}\text { Infected } \\
\text { No* }^{*}\end{array}$ & $\%$ & No & $\begin{array}{l}\text { Infected } \\
\text { No* }\end{array}$ & $\%$ & No & $\begin{array}{l}\text { Infected } \\
\text { No }^{*}\end{array}$ & $\%$ \\
\hline $\begin{array}{r}0-4 \\
5-14 \\
15-24 \\
25-34 \\
35-44 \\
45-54 \\
55-64 \\
65+\end{array}$ & $\begin{array}{r}0 \\
2 \\
27 \\
26 \\
8 \\
3 \\
2 \\
0\end{array}$ & $\begin{array}{l}0 \\
0 \\
5 \\
2 \\
3 \\
1 \\
1 \\
0\end{array}$ & $\begin{array}{r}0 \\
2 \\
32 \\
28 \\
11 \\
4 \\
3 \\
0\end{array}$ & $\begin{array}{r}4 \\
33 \\
63 \\
32 \\
10 \\
17 \\
17 \\
3\end{array}$ & $\begin{array}{r}2 \\
5 \\
22 \\
12 \\
8 \\
11 \\
10 \\
3\end{array}$ & $\begin{array}{r}50.0 \\
15.2 \\
34.9 \\
37.5 \\
80.0 \\
64.7 \\
58.8 \\
100.0\end{array}$ & $\begin{array}{r}6 \\
25 \\
70 \\
28 \\
22 \\
23 \\
11 \\
5\end{array}$ & $\begin{array}{r}1 \\
3 \\
25 \\
12 \\
14 \\
11 \\
6 \\
5\end{array}$ & $\begin{array}{r}16.7 \\
12.0 \\
35 \cdot 7 \\
42.9 \\
63 \cdot 6 \\
47 \cdot 8 \\
54 \cdot 5 \\
100 \cdot 0\end{array}$ & $\begin{array}{r}10 \\
58 \\
133 \\
60 \\
32 \\
40 \\
28 \\
8\end{array}$ & $\begin{array}{r}3 \\
8 \\
47 \\
24 \\
22 \\
22 \\
16 \\
8\end{array}$ & $\begin{array}{r}30 \cdot 0 \\
13 \cdot 8 \\
35 \cdot 3 \\
40 \cdot 0 \\
68 \cdot 8 \\
55 \cdot 0 \\
57 \cdot 1 \\
100 \cdot 0\end{array}$ \\
\hline Total & 68 & 12 & 80 & 179 & 73 & 43.0 & 190 & 77 & $41 \cdot 6$ & 369 & 150 & $40 \cdot 7$ \\
\hline
\end{tabular}

-Infected refers to presence of at least one positive HBV marker. 
the Malay home contacts was the same $(43.8 \%$ and $43.5 \%$ respectively) but significantly higher than that of the ethnic Indian ( $<<0.005)$ (table 3$)$.

It was also found that spouses and parents of acute cases had a significantly higher prevalence rate of infection when compared with that of children, siblings, and other blood relatives of acute cases living in the same household (table 4). No significant difference between prevalence of infection and household size was noted (table 5).

Table 3 Hepatitis $B$ prevalence rate of Indian and nonIndian household contacts of 80 acute cases of hepatitis $B$

\begin{tabular}{|c|c|c|c|c|}
\hline \multirow[b]{2}{*}{ Ethnic group } & \multirow[b]{2}{*}{$\begin{array}{l}\text { Acute } \\
\text { cases }\end{array}$} & \multicolumn{3}{|c|}{ Home contacts } \\
\hline & & No & $\begin{array}{l}\text { Infected } \\
\text { No }^{*}\end{array}$ & $\%$ \\
\hline $\begin{array}{l}\text { Indian } \\
\text { Non-Indian }\end{array}$ & $\begin{array}{l}10 \\
70\end{array}$ & $\begin{array}{r}51 \\
318\end{array}$ & $\begin{array}{r}11 \\
139\end{array}$ & $\begin{array}{l}21 \cdot 6 \\
43 \cdot 7+\end{array}$ \\
\hline Total & 80 & 369 & 150 & 40.7 \\
\hline
\end{tabular}

*Infected refers to the presence of at least one HBV marker.

$\div \mathrm{p}<0.005$

\section{SOURCE OF INFECTION}

The majority ( 55 or $68.8 \%$ ) of the acute cases had no identifiable source of infection such as exposure to parenteral procedures, contact with jaundiced persons, or overseas travel within the past six months prior to onset of jaundice. None of the families visited had specifically complained of nuisances caused by mosquitoes or bed bugs. Only two of the infected household contacts had a history of weeping eczema or impetiginous lesions, and 16 had had a recent bleeding episode.
Table 4 Prevalence rate of hepatitis $B$ infection among household contacts of 80 acute cases of hepatitis $B$ by relationship to the acute case

\begin{tabular}{lccl}
\hline $\begin{array}{l}\text { Relationship to } \\
\text { the acute case }\end{array}$ & Number & $\begin{array}{l}\text { No } \\
\text { infected }\end{array}$ & $\begin{array}{l}\% \\
\text { infected }\end{array}$ \\
\hline Parent & 81 & 50 & $61 \cdot 7^{\mathrm{a}}$ \\
Siblings & 168 & 53 & $31 \cdot 5^{\mathrm{b}}$ \\
Child & 64 & 25 & $39 \cdot 1^{\mathrm{c}}$ \\
Spouse & 22 & 16 & $72 \cdot 7^{\mathrm{d}}$ \\
$\begin{array}{l}\text { Other blood } \\
\text { relative }\end{array}$ & 34 & 6 & $17 \cdot 6^{\mathrm{e}}$ \\
Total & 369 & 150 & $40 \cdot 7$ \\
\hline
\end{tabular}

With at least one HBV marker.

The following differences between the pairs are statistically significant:

$a$ and $b(p<0.0001)$

$a$ and $c(p<0.05)$

$a$ and $e(p<0.0001)$

$d$ and $b(p<0.001)$

$d$ and $c(p<0.05)$

$d$ and $e(p<0.0001)$

Table 5 Prevalence of hepatitis $B$ infection among household contacts of acute hepatitis $B$ cases by maximum household size

\begin{tabular}{llll}
\hline Household size & $\begin{array}{l}\text { No of home } \\
\text { contacts }\end{array}$ & $\begin{array}{l}\text { No* } \\
\text { infected }\end{array}$ & $\begin{array}{l}\text { \% } \\
\text { infected }\end{array}$ \\
\hline 3-5 persons & 139 & 57 & 41.0 \\
6-9 persons & 193 & 78 & 40.4 \\
10 persons & 37 & 15 & 40.5 \\
Total & 369 & 150 & 40.7 \\
\hline
\end{tabular}

*Infected refers to the presence of at least one HBV marker.

MODE OF TRANSMISSION

Analysis of the data obtained for 88 infected and 97 non-infected home contacts in the $\mathbf{4 0}$ families studied

Table 6 Analysis of the association of sharing household and personal articles and bedroom and eating together at meals, and transmission of hepatitis $B$ infection in 40 Singapore families.

\begin{tabular}{|c|c|c|c|c|c|c|c|}
\hline \multirow[b]{2}{*}{ Items } & \multicolumn{3}{|l|}{ Infected ${ }^{+}$} & \multicolumn{3}{|l|}{ Well } & \multirow[b]{2}{*}{$\begin{array}{l}p \\
\text { value }\end{array}$} \\
\hline & $\begin{array}{l}\text { Shared with } \\
\text { acute cases }\end{array}$ & $\begin{array}{l}\text { Did not } \\
\text { share with } \\
\text { acute cases }\end{array}$ & $\begin{array}{l}\% \\
\text { Shared with } \\
\text { acute cases }\end{array}$ & $\begin{array}{l}\text { Shared with } \\
\text { acute cases }\end{array}$ & $\begin{array}{l}\text { Did not } \\
\text { share with } \\
\text { acute cases }\end{array}$ & $\begin{array}{l}\% \\
\text { Shared with } \\
\text { acute cases }\end{array}$ & \\
\hline Towel/handkerchief/clothing & 59 & 29 & $67 \cdot 0$ & 35 & 62 & $36 \cdot 1$ & $<0.0001^{*}$ \\
\hline Eating/drinking utensils & 60 & 28 & $68 \cdot 2$ & 61 & 36 & $62 \cdot 9$ & NS \\
\hline Toothbrush & 38 & 50 & $43 \cdot 2$ & 6 & 91 & $6 \cdot 2$ & $<0.000001^{*}$ \\
\hline Nail clippers & 88 & 0 & 100 & 97 & 0 & 100 & NS \\
\hline Razor & 27 & 61 & 30.7 & 5 & 92 & $5 \cdot 2$ & $<0.0001$ \\
\hline Toy & 0 & 88 & 0 & 0 & 97 & 0 & NS \\
\hline Cigarette/pipe & 0 & 88 & $\mathbf{0}$ & $\mathbf{0}$ & 97 & 0 & NS \\
\hline Comb & 48 & 40 & $54 \cdot 5$ & 31 & 66 & $32 \cdot 0$ & $<0.005^{\circ}$ \\
\hline Bedroom & 29 & 59 & 33.0 & 26 & 71 & 26.8 & NS \\
\hline Bed/bedding & 47 & 41 & 53.4 & 34 & 63 & $35 \cdot 1$ & $<0.05^{*}$ \\
\hline Eating together at meals & 88 & 0 & 100 & 97 & 0 & 100 & NS \\
\hline
\end{tabular}

+ Infected refers to asymptomatic household members with at least one HBV marker.

NS = not significant.

statistically significant. 
showed that sharing of various personal and household items between infected family members and acute cases was associated with HBV transmission. These items included toothbrush, towel, handkerchief, clothing, razor, and comb. Sharing of bed and bedding was also a risk factor, but sleeping in the same bedroom, eating together at meals, and sharing of eating and drinking utensils were not associated with an increased risk of transmission of infection (table 6). No significant difference was observed between the infected and non-infected household members with regard to exposure to various parenteral procedures including shaving in a barber shop, overseas travel, and habitual nail biting.

FOLLOW UP OF ACUTE CASES AND FAMILY CONTACTS

Of the $\mathbf{4 0}$ families selected for rebleeding, only 37 $(92.5 \%)$ of 40 acute cases and $147(79.5 \%)$ of 185 home contacts responded in spite of repeated persuasion. Eleven $(29.7 \%)$ of the acute cases continued to harbour HBs $\mathrm{Ag}$ in the blood stream and are therefore termed as chronic carriers. Of these carriers, $5(45.7 \%)$ were highly infectious with $\mathrm{HBe}$ $\mathrm{Ag}$ positivity. The other 16 acute cases recovered completely with clearance of $\mathrm{HBs} / \mathrm{HBe}$ antigenaemia and development of anti-HBc/anti-HBs.

Six $(8 \cdot 8 \%)$ of 68 susceptible seronegative home contacts (with no HBV marker) seroconverted: HBs $\mathrm{Ag}$ (1), anti-HBc/anti-HBs (1), anti-HBs (1), and anti-HBc (3). There were $16 \mathrm{HBs} \mathrm{Ag}$ carriers (11 $\mathrm{HBe} \mathrm{Ag}$ positive) among the home contacts, and two of them lost their $\mathrm{HBe} \mathrm{Ag}$ but not $\mathrm{HBs} \mathrm{Ag}$ six months later. As for the 63 family members with anti-HBc/anti-HBs, seven lost their anti-HBc during follow up.

None of the 369 home contacts of the acute cases developed any symptoms suggestive of clinical hepatitis throughout the duration of surveillance.

\section{Discussion}

Seroepidemiological surveys of the families of acute hepatitis B carried out at the time when the cases were clinically ill revealed that $85 \%$ of the households had at least one other member with asymptomatic $\mathrm{HBV}$ infection. The $\mathrm{HBs} \mathrm{Ag}$ prevalence rate in apparently healthy household members was $20 \%$, much higher than the $6 \%$ prevalence in the general population. ${ }^{2}$ Most of these carriers $(60 \%)$ were highly infectious with $\mathrm{HBe} \mathrm{Ag}$ positivity. The onset of infection and duration of carrier state or past infection among the family members studied were unknown. But the acute case could not be the first to be infected in the home where there was one other infected member. As a large proportion of the acute cases had no obvious source of parenteral or non-parenteral exposure outside the household setting before they became ill, most of them must have acquired the infection from asymptomatic carriers within the same household.

The presence of a carrier in a family sets the stage $T$ for subsequent spread to other family members $\stackrel{D}{\Omega}$ either perinatally or horizontally. The number of asymptomatic children in this study was too few to $\vec{F}$ demonstrate perinatal transmission from $\mathrm{HBs} \mathrm{Ag} \stackrel{\text { ? }}{+}$ carrier mothers (table 2). All the three infected children in this age group were $\mathrm{HBe} \mathrm{Ag}$ positive. Only the mother of a 9-month-old infant was $\mathrm{HBe} \mathrm{Ag}$ positive; the mother of a 2-year-old carrier had a past HBV infection (anti-HBs positive), while the mother of a 4-year-old child was an acute case.

Horizontal transmission from carriers to other family contacts was probably polymodal. Environmental contamination by blood, saliva, and other body secretions could lead to infection of others in the home..$^{17}{ }^{18}$ Blood is the most efficient vehicle of transmission as $\mathrm{HBV}$ in dried blood may remain infective for weeks. ${ }^{1920}$ The habit of sharing various personal and household articles within the $\vec{N}$ home, as demonstrated in this study, provided af important mechanism for the transfer of $\mathrm{HBV}$ fronf carriers to other family members by both parentera (eg, via contaminated toothbrush) an $\&$ non-parenteral (eg, via contaminated bedding routes. Although $\mathrm{HBV}$ is known to be present in the $\overrightarrow{0}$ saliva of carriers, and $\mathrm{HBs} \mathrm{Ag}$-positive swab or samples had been obtained from contaminated drinking utensils, ${ }^{17}$ eating together at meals and sharing of eating and drinking utensils among the household members did not pose any significant risk. It appears that under natural conditions it is extremely difficult for HBV to be introduced from contaminated eating utensils and food into the blood circulation of susceptible home contacts with intact oral mucosa to give rise to an infection. As there was no increased risk of acquiring $\mathrm{HBV}$ infection through sleeping in the same bedroom, airborne transmission could not be an important mechanism in the spread of infection, as had been postulated by some investigators. ${ }^{24}$ Therefore, segregation of carriers from other family members at meals, or from sleeping in the same bedroom, is not justifiable.

While sexual contact is a well recognised route of transmission, ${ }^{12122}$ studies have shown that the $\frac{D}{O}$ prevalence of hepatitis B infection among the spouses was relatively low when compared with that $N$ of other relatives in family settings. ${ }^{4-6}$ In this study, the prevalence of infection of the spouses was not significantly higher than that of the parents of acute cases. This confirmed that close contact, rather than 
specifically sexual contact, was the determining factor in the person-to-person transmission of infection. No relation between hepatitis B prevalence and household size was observed, probably because all the families stayed in premises provided with modern sanitary facilities. The significantly lower hepatitis B prevalence among the Indian home contacts compared to that of the Chinese and Malay ethnic groups was not due to differences in age-sex distribution of $\mathrm{HBV}$ markers, $\mathrm{HBe} \mathrm{Ag}$ status of the carriers, or differences in socioeconomic levels in the families studied. It was believed to be due to differences in racial and host genetic susceptibility and their responses to HBV infection. ${ }^{23}$

The HBV markers status and its infectivity among the infected family members varied with time. A surprisingly high proportion (30\%) of the acute cases became chronic carriers; about half of them were $\mathrm{HBe} \mathrm{Ag}$ positive. They thus provide an additional source of carriers in the infected household. The number of existing carriers remained unchanged during follow-up, although $18 \cdot 2 \%$ of them lost their ' $e$ ' antigen status. Nine per cent of the seronegative contacts acquired the infection asymptomatically. Prolonged exposure to the carriers within the home will ultimately result in infection of most susceptible members of the family, either asymptomatically or clinically. This was shown in another study where between $40 \%$ and $50 \%$ of the family members of patients with chronic hepatitis B and hepatocellular carcinoma were $\mathrm{HBs} \mathrm{Ag}$ carriers, and $64 \%-92 \%$ had past $\mathrm{HBV}$ infection. ${ }^{25}$

Health education on the prevention of hepatitis B transmission in the household of an acute case should be based on sound epidemiological data. Prejudice and indiscriminate segregation of cases or carriers should be avoided. Cases and carriers should be advised to practise good personal hygiene, including proper handwashing, and to handle or dispose of articles contaminated with blood and other bloody secretions carefully. Household members should avoid the habits of sharing toothbrushes, towels, handkerchiefs, clothes, razors, and combs. They should be routinely screened for HBV markers, and hepatitis $B$ vaccination is strongly recommended for all those found to be susceptible to infection.

We thank Mr Hussain bin Yusoff for field investigations, Mrs $\mathrm{K}$ Indumathy for secretarial assistance, and all others who contributed to this study.

\section{References}

${ }^{1}$ Heathcote J, Sherlock S. Spread of acute type-B hepatitis in London. Lancet 1973; i: 1468-70.
${ }^{2}$ Goh KT. Epidemiological surveillance of communicable diseases in Singapore. Tokyo: Southeast Asian Medical Information Center, 1983: 131-50.

${ }^{3}$ Tong MJ, Weiner JM, Ashcavai MW, Redeker AG, Camparini S, Vyas GN. A comparative study of hepatitis $B$ viral markers in the family members of Asian and non-Asian patients with hepatitis $B$ surface antigen-positive hepatocellular carcinoma and with chronic hepatitis B infection. J Infect Dis 1979; 140: 506-12.

${ }^{4} \mathrm{Liu} \mathrm{CB}$, Lee Y, Hu ZH. Familial clustering of $\mathrm{HBs} \mathrm{Ag}$ in China. In: Mackenzie JC, ed. Viral diseases in South-East Asia and the Western Pacific, Australia: Academy Press 1982; 366-70.

${ }^{5}$ Szmuness W, Prince AM, Hirsch RL, et al. Familial clustering of hepatitis B infection. N Engl J Med 1973; 289: 1162-6.

${ }^{6}$ Bernier RH, Sampliner R, Gerety R, Tabor E, Hamilton $F$, Nathanson N. Hepatitis B infection in households of chronic carriers of hepatitis B surface antigen: factors associated with prevalence of infection. Am J Epidemiol 1982; 116: 199-211.

${ }^{7}$ Szumuness W, Harley EJ, Prince AM. Intrafamilial spread of asymptomatic hepatitis B. Am J Med Sci 1975; 270-304.

${ }^{8}$ Heathcote J, Gateau P, Sherlock S. Role of hepatitis B antigen carriers in non-parenteral transmission of the hepatitis B virus. Lancet 1974; ii: 370-2.

${ }^{9}$ Perillo RP, Gelv L, Campbell C, et al. Hepatitis B e antigen, DNA polymerase activity, and infection of household contacts with hepatitis B virus. Gastroenterology 1979; 76: 1319-25.

${ }^{10}$ Stevens EE, Beasley PR, Tsui J, Lee WC. Vertical transmision of hepatitis B antigen in Taiwan. $N$ Engl $J$ Med 1975; 292: 771-4.

${ }^{11}$ Okuda K, Yamada T, Miyakawa Y, Mayami M. Hepatitis $B$ surface antigen in the serum of infants after delivery from asymptomatic carrier mothers.J Paediatr 1975; 87: 360-3.

${ }^{12}$ Brotman B, Prince AM, Godfrey HR. Role of arthropods in transmission of hepatitis B virus in the tropics. Lancet 1973; i: 1305-8.

${ }^{13}$ Wills W, Larouze B, London WT, et al. Hepatitis B virus in bed bugs (Cimex hemipterus) from Sengal. Lancet 1977; ii: 217-9.

${ }^{14}$ Foster O, Ajudukiewicz, Ryder R, Whittle H, Zuckerman AJ. Hepatitis B virus transmission in West Africa: a role for tropical ulcer? Lancet 1984; i: 576-7.

${ }^{15}$ Chan SH, Chew TS, Oon CJ, Ho KT, Seah CS. Acute viral hepatitis in Singapore. Sing Med J 1982; 23: 90-2.

${ }^{16}$ Chan SH, Tan KL, Goh KT, et al. Maternal-child hepatitis $\mathrm{B}$ virus transmission in Singapore. Int J Epidemiol 1984 (in press).

${ }^{17}$ Paterson NJ, Barrett DH, Bond WW, et al. $\mathrm{HBs} \mathrm{Ag}$ in saliva, impetiginous lesions and the environment in two remote Alaskan villages. Appl Environ Microbiol 1976; 32: $572-4$.

${ }^{18}$ Heathcote J, Cameron CH, Dane DS. Hepatitis B antigen in saliva and semen. Lancet 1974; $\mathrm{i}$ : 71-3.

${ }^{19}$ Bond WW, Favero MS, Paterson NJ, et al. Survival of hepatitis B virus after drying and storage for one week. Lancet 1981; i: 550.

${ }^{20}$ Zachoval R, Frosner G, Deinhardt F, Hoss D. Persistence of hepatitis $B$ virus antigens in dried blood. Lancet 1981; i: 778 .

${ }^{21}$ Wright RA. Hepatitis B and the HBs Ag carrier: an outbreak related to sexual contact. JAMA 1975; 232: 717-21. 
${ }^{22}$ Redeker AG, Mosley JW, Gocke DJ, et al. Hepatitis B immune globulin as a prophylactic measure for spouses exposed to acute type B hepatitis. $N$ Engl J Med 1975; 293: 1055-9.

${ }^{23}$ Quak SH, Singh R, Oon CJ, Wong HB. A cross-sectional study of hepatitis B immune status in Asian children in Singapore. Ann Trop Paediatr 1982; 2: 53-6.
${ }^{24}$ Villarejos VM, Visona KA, Gutierrez DA, Rodriguez AA. Role of saliva, urine and faeces in the transmission of type B hepatitis. New Engl J Med 1974; 291: 1375-8.

${ }^{25}$ Oon CJ, Chan L, Chan SH, et al. Immune status of various populations to hepatitis B virus and a strategy for its prevention and immunoprophylaxis. In: Develop Biol Standard 1983; 54: 295-305 (Basel: Karger). 